\title{
Judicial Independence and Peace Duration: An Assessment of Political Institutions in the Post-Conflict Environment
}

Author: Ryan J. Madden

Faculty Mentors: John Ishiyama and Eric Keels, Department of Political Science, College of Arts and Sciences, University of North Texas

College and Affiliation: Department of Political Science, Harpur College of Arts and Sciences, State University of New York at Binghamton 


\section{Bio:}

Ryan Madden is a political science major at the State University of New York at Binghamton, with a concentration in international relations and global affairs. He also minors in environmental studies, with a focus on global environmental politics. His previous research has investigated counter-terrorism policies in the European Union, economic development trends in the African continent, and the geographical determinants of intra-state conflict. Upon graduation he may take part in Teach for America or apply for a position in the Peace Corps. 


\begin{abstract}
:
The purpose of this research is to assess the role that an independent judiciary serves in the postconflict environment. The existing literature on post-conflict environments has suggested that mitigating security dilemmas best ensures durable peace and that the presence of political institutions that safeguard against security dilemmas are necessary in promoting this peace. I argue that an independent judiciary is endowed with the security-assuring attributes that the previous literature claims to be necessary for political institutions to have in order to facilitate peace in post-conflict societies. I employ a Cox Proportional Hazards Model to test the effect that the presence of an independent judiciary has on the onset of renewed conflict using the dataset in Mason et al. (2011) and the CIRI Human Rights Data Project. Although the findings in this paper do not support the theoretical argument I set forth, they offer interesting implications for future research in this field of study. I offer a variety of explanations for these results that lend themselves to further inquiry in the study of post-conflict political institutions.
\end{abstract}




\section{Introduction}

The role that political institutions play in sustaining peace in post-conflict societies has not been the focus of much scholarly work. The existing literature discusses the importance of establishing institutions, but does not address the specific connection these institutions have on peace duration. This is surprising given that institutions help address the security concerns that arise in the aftermath of civil war by facilitating the transition from violence to the formation of a stable political environment. Security concerns are related to the instability, commitment problems, and lack of trust that endures between opposing groups at the termination of civil conflict. Since one of the best predictors of a civil war is whether or not a country fought a previous civil war, it is important to investigate the factors responsible for sustaining peace in war-torn societies.

The purpose of this research is to investigate the role that an independent judiciary plays in maintaining peace at the end of civil wars. Serving as a neutral arbiter between warring factions, an independent judiciary will function as a dependable political entity in ensuring the rule of law in the aftermath of conflict. An independent judiciary can solve the security dilemmas faced by opposing groups by instilling trust in the political system. An independent judicial system can ensure the fair implementation of laws, control the excess of executive and legislative

power, create an atmosphere conducive to economic growth, and monitor the fair enactment of settlement agreements.

In order to make the case that an independent judiciary has a positive effect on peace duration, I will first detail the factors that lead to the emergence of security dilemmas in the aftermath of conflict. I will then assess the role that political institutions serve in facilitating peace post-conflict. Before building upon a theoretical argument regarding the judiciary in post- 
conflict societies and testing it empirically, I will note how independent judicial systems have served to facilitate societal stability in post-communist countries and discuss a case study of the judiciary in Rwanda. By detailing the merits of political institutions in lessening the reemergence of civil war and by describing the beneficial aspects of independent judicial systems, I will make the argument that such systems contribute to peace duration in the aftermath of civil wars.

\section{Literature Review}

Attention to post-conflict political environments has long been a focus of research (Hartzell 1999; Hartzell, Hoddie, and Rothchild 2001; Mason, Gurses, Brandt, and Quinn 2011; Quinn, Mason, and Gurses 2007; Walter 2004) and the empirical literature has suggested that alleviating security dilemmas is a necessity in maintaining peace after a conflict has ended. Insecurities that persevere at the end of conflict are associated with a myriad of factors, such as military outcome of the conflict, the role of third-parties in conflict management, the longevity of the previous war, the persistence of an incentive structure that makes reengaging in violence more probable, the establishment of political institutions, and the economic opportunities available to groups after the war has ended.

Quinn, Mason, and Gurses (2007) as well as Mason, et al. (2011) argue that peace duration is dependent on the military outcome of a conflict. Both articles argue that military outcomes determine whether or not a condition of dual sovereignty is maintained in the aftermath of war. According to Tilly (1978) dual sovereignty involves the "appearance of contenders or coalition of contenders, advancing exclusive alternative claims to the control over the government" and "the incapacity or unwillingness of the government or its agents to suppress the challenger coalition" (Tilly 1978, 200). The extent to which dual sovereignty persists in postconflict society is influenced by whether or not the previous war resulted in a military victory or 
a negotiated settlement. Quinn, Mason, and Gurses (2007) and Mason, et al. (2011) claim that military victories end the conditions of dual sovereignty by dismantling the organizational capacity of rebel groups. On the other hand, negotiated settlements preserve elements of it by rendering issues unresolved. The empirical data found in these articles suggest that rebel victories are more stable than government victories and that negotiated settlements combined with international peacekeeping forces produce a peace that is more stable than peace following a government victory. These findings led to the conclusion that sustaining peace necessitates the establishment of political institutions that reduce the conditions of dual sovereignty and reintegrate former enemies into a single polity (Quinn et al. 2007, 16). These measures ostensibly ameliorate the security concerns opposing groups face during the transition from violence to peace.

Walter (2004), as well as Quinn, Mason, and Gurses (2007) and Mason, et al. (2011) investigate the role that incentives to rejoin rebel groups play in the peace maintenance process. Walter (2004) asserts that current incentives to reengage in violence are more important than the attributes of the previous civil war in determining whether or not peace will be preserved. An individual's incentive to rebel will be dependent on a few factors, including their economic situation, their expected probability of success in reengaging in conflict, and their access to political participation. Walter found that the longer a previous war had lasted, the less likely a renewed conflict would ensue. Hartzell, Hoddie, and Rothchild (2001) further substantiate this claim by noting that in the short-term, settlements negotiated after extended periods of domestic conflict are more likely to decrease the onset of renewed war. Evidently, long civil wars convince groups of the futility of prevailing and convince them that mitigating security concerns through accommodation is likely to be more fruitful. 
More importantly, Walter's findings determined that the likelihood of returning to civil war was contingent on the overall well-being of a country's population and the accessibility of government decision making to the average citizen. She found that higher infant mortality rates in the first few years following the end of war are positively and significantly related to renewed war (Walter 2004, 380), which suggests that rebels re-enlist in organizations when dismal conditions endure at home. Quinn, Mason, and Gurses (2007) support the view that economic development helps offset the likelihood of repeated conflict. Economic development does protect a nation against a relapse of civil war "by making the opportunity costs of conflict higher relative to the payoffs from sustaining the peace" (22). They found that both higher rates of GDP per capita and lower rates of infant mortality reduce the probability of civil war recurrence.

States with higher living standards and those with more accessible, competitive political systems should be better equipped to escape conflict traps by reducing the incentives for individuals to fight (Walter 2004). Individuals are more willing to incite renewed violence where there are scarcer opportunities to influence the actions of government. Citizens who are able to express preferences about policies and who are assured of civil liberties and political inclusiveness are less likely to re-join rebel militaries (Walter 2004, 385).

Hartzell (1999) asserts that security dilemmas in post-conflict societies are the foundation for the failure of peace agreements. She sets forth three main security concerns in the postconflict environment:

1. “that one's opponent may gain control of the coercive apparatus of the new state,

2. that one's opponent may gain an advantage in the allocation of political power within the new state, and 
3. that one's opponent may gain an economic advantage within the new state." $(1999,4)$.

The establishment of institutions that seek to address these security concerns will help facilitate peace as they serve to balance power among rival groups in the transition stage in the aftermath of conflict. Institutions reduce uncertainty among groups as they facilitate interactions between them and regulate human behavior. In her research, she found that the establishment of institutions leads to more stable peace agreements in post-conflict societies. Her work suggests that institutions play a large role in neutralizing the security dilemmas faced by opponents and facilitate the move by groups toward more cooperative relations.

Building upon previous work, Hartzell, Hoddie, and Rothchild (2001) analyzed the political environment in the aftermath of civil wars and the type of settlement provisions agreed upon in the negotiation processes. In this paper, they argue that institutions are needed to safeguard against predatory behavior of elites; that weak institutions increase insecurities among opposing groups; and that the lack of an administrative or judicial body able to oversee the implementation of rules in a fair approach can increase the incentives of individuals to address grievances by returning to violence (185).

In their assessment of the political environment and provisions of settlement agreements, Hartzell, Hoddie, and Rothchild (2001) found that arrangements for territorial autonomy provisions in negotiated settlements and the offer of third-party security have a positive correlation with peace preservation. Bigombe, Collier, and Sambanis (2000) confirm the positive role that third parties have in maintaining peace. Their work demonstrates that multi-dimensional UN peacekeeping operations are most effective in safeguarding peace duration. Multidimensional missions that include military, political, and developmental roles reduce risk factors 
that exacerbate security concerns in post-conflict nations (Bigombe, Collier, and Sambanis 2000, 347). These findings further support the notion that security dilemmas are central to peace settlement success or failure.

Further expanding on previous work, Hartzell and Hoddie (2003) assess the role that power-sharing institutions serve in decreasing the likelihood of renewed political violence. They coded civil war agreements that occurred after WWII to assess the number of power-sharing provisions that these settlements included. They used a regression model and a proportional hazards model to test the statistical significance of these provisions on settlement failure. Their quantitative analysis revealed that power-sharing agreements that include four dimensions of power sharing (political, military, territorial, and economic) have higher survival ratings than agreements with only a single provision. It was found that each additional power-sharing provision reduced the probability of settlement failure by $53 \%$ (327). Thus, the greater the overall number of power-sharing institutions, the more probable that peace duration will hold.

The incorporation of multiple dimensions of power-sharing in a negotiated civil war settlement is beneficial to the prospects of long-term peace by serving as "a source of protection against the failure to implement any single power-sharing provision of the settlement" (Hartzell and Hoddie 2003, 321). Making security-related issues central to the agenda in negotiations is important, and multi-level power-sharing agreements designed to combat safety concerns have demonstrated that they are more effectual in maintaining peace than ones solely focused on political-decision making.

Although there has been considerable literature on peace settlements and peace duration, and some suggestion that power sharing arrangements are important, there is remarkably little work on the effects of specific political institutions. Indeed, while there has been some literature 
that has suggested that certain institutional choices like electoral systems (Horowitz 1985; Duverger 1955), presidentialism (Linz 1992), and federalism (Bakke and Wibbels 2005) affect conflict onset, there has been little or no research that examines the effect of judicial institutions, and certainly none that has examined the effects of judicial systems on peace duration. What role do independent judicial systems play in facilitating peace and assuring political stability in countries?

The judicial branch serves a very significant role in government and politics. Judicial systems are responsible for developing and maintaining the rule of law. According to Larkins' (1996) thorough constitutional and judicial review, "judges cannot only mediate conflicts between political actors, but also prevent the arbitrary exercise of government power" (606). Courts can serve as monitors of cooperative agreements by providing information and disclosing the nature of alleged breaches of power (Staton and Reenock 2010). Judicial power serves to constrain the power of other branches of government. By interpreting laws and possessing the power to overturn ones deemed unconstitutional, the judiciary can maintain a system of checks and balances that promotes governmental stability. For a judiciary to be deemed independent, it must be impartial and insulated from the influence of politics. The inability to be easily removed from office, long-tenure, and fixed salaries help maintain these conditions by minimizing the influence of political expediency, giving judges the ability to focus on the law and other legal principles (Smithey and Ishiyama 2000, 166).

Independent judicial systems can help establish legitimacy in a political system when the public views other political institutions as self-serving and corrupt. In an analysis of eight postcommunist countries in Eastern Europe, Smithey and Ishiyama (2000) demonstrate support for the notion that the degree of popular trust, relative to the executive branch, affects the rates of 
judicial activism in these countries. This finding supports the assertion that courts can increase their policy influence when other branches of government are divided by political gridlock or have low levels of public support (Smithey 2002, 738). This finding may be pertinent to the study of independent judicial systems in post-conflict societies. Since security issues are at the foundation of settlement failures, an independent judiciary may be able to serve as source of stability between divisive factions after the formation of a new government.

In an assessment of the judiciary in Rwanda, Rugege (2005) claims that judicial independence "... is a prerequisite for a society to operate on the basis of rule of law. It is essential for the purpose of maintaining public confidence in the judiciary" (411). The article proclaims that independent judiciaries help usher in societal stability and that the establishment of such institutions lowers the incentives for individuals to disturb the peace, since individuals will have confidence that courts can resolve disputes in an impartial manner (414-415). Rugege (2005) goes on to assert that judicial independence helps create the conditions for an open economy. When the rule of law is properly enforced and there is an assurance of legal security and foreseeability, it gives investors more confidence to do business in a country.

Acemoglu, Johnson, and Robinson (2001); Barro (1997); North (1990) have supported this view by noting that courts encourage economic development by rendering rights credible. Limits on the state by the judiciary uphold governmental promises to respect assets, thus lowering the stakes of holding power, which facilitates the maintenance of order (Staton and Reenock 2010). As investment increases, economic growth occurs. This growth helps combat poverty and raise standards of living. These phenomena occurred in Rwanda in the aftermath of the 1994 genocide. Between 1982 and 1992, GDP per capita declined 1.5\% annually, but between 1995 and 2000, growth averaged 8.1\% annually and income poverty levels were 
reduced by $18 \%$ (Rugege 2005,424 ). Rugege claims "the stability and economic growth has, among other factors, been due to confidence in the country fostered by good governance, commitment to the rule of law, and judicial independence on the part of the post-genocide government of national unity" (424).

\section{Theoretical Argument}

An independent judiciary will promote political and societal stability at the end of a civil war by ending conditions of dual sovereignty in the post-conflict environment, by increasing public access to political participation, by encouraging conditions conducive to economic growth, and by addressing a multitude of other security dilemmas opposing groups confront in the aftermath of conflict.

Quinn, Mason, and Gurses (2007) assert that "the persistence of dual sovereignty into the post-conflict environment is the primary structural condition for the resumption of civil war" (9). As stated before, dual sovereignty is the appearance of competing societal coalitions that assert alternative claims to the control of government in a country. The authors conclude that sustaining peace necessitates the establishment of political institutions that reduce the conditions of dual sovereignty and reintegrate former enemies into a single polity. An independent judiciary will be able to serve as one of these institutions as it functions as a neutral arbiter between warring factions in society.

An independent judiciary that indiscriminately enforces the rule of law will help mitigate contentions over access to power and concerns over the oppressiveness of a particular government that are held by opposing sides in the aftermath of civil conflict. By providing an outlet to properly address grievances, opposing groups will have confidence in the political environment, lowering the incentives to address grievances through violent action. Insecurities 
over the distribution of political power foster the conditions for dual sovereignty. By moderating political conditions through the impartial enforcement of the rule of law, independent judiciaries can combat the circumstances that lead to dual sovereignty. With a reduction in the persistence of dual sovereignty, post-conflict societies can sustain a more durable peace.

An independent judiciary will further contribute in lowering individual incentives to rejoin rebel groups by addressing insecurities pertaining to political participation that persist at the end of conflict. Walter (2004) concludes that countries with a more open and accessible political system are less likely to re-engage in violent conflict. Limited opportunity to influence the actions of government will increase individual incentives to engage in violent action. If nonviolent means do not exist to improve an individual's situation, engaging in violence may be seen as the only viable alternative to impact political processes. An accessible, accountable, and open political system that ensures civil liberties and political inclusiveness will decrease the likelihood of citizens re-joining rebel armies (Walter 2004, 385). An independent judiciary can serve to ensure the aforementioned conditions.

By providing an outlet to manage grievances, citizens can use the judicial system to address their concerns over actions of the government, offering citizens a voice in the political system. Independent judiciaries, serving as neutral arbiters between opposing groups in society, help ease insecurities over the control of political power. Functioning as a mediator between the government and society, independent judicial systems can help ensure accountability in the enforcement of laws, the guarantee of civil liberties, and the establishment of an open political system. Setting the conditions for a more stable political environment will reduce the likelihood that groups will resort to violence in order to address their grievances. 
Independent judiciaries can also help resolve the security concerns that Hartzell (1999) claim to be the most significant in post-conflict societies. These concerns are over the control of the coercive power of the state, the allocation of political power in the state, and the allocation of economic resources (4). With regard to the coercive power of the state, an independent judiciary can ensure that no political entity, whether it is the executive or legislature, exerts overt force over a societal group. Acting as an intermediary between the government and the people, they will uphold the rule of law and provide a system of checks and balances against excess use of power among other branches of government.

A similar argument holds for the allocation of political power. A separate and independent judiciary will mitigate disproportionate advantages in political power by monitoring the actions of governments through the safeguarding of the rule of law. The situation in Nigeria supports this idea. Serving as an impartial arbiter, separate from the influence of the executive and legislative branches, the Nigerian judicial system has been able to fight electoral fraud, uphold the rule of law in the country, and instill greater confidence in the political system. The independent judicial system has helped sustain the Fourth Republic in Nigeria (Enweremadu 2009).

The concern over the distribution of economic power cannot be directly addressed by an independent judicial system but the presence of an independent judiciary has proven to be an effective means to increase economic development in a country (Acemoglu, Johnson, and Robinson 2001; Barro 1997; North 1990; Rugege 2005; Staton and Reenock 2010). When the rule of law is properly enforced and there is an assurance of legal security and foreseeability, it gives investors more confidence to do business in a country. Investment promotes job creation, which leads to a decrease in rates of poverty. As poverty is reduced in a country, the standards of 
living rise which advance the well-being of a country as a whole. As Walter (2004) and Quinn, Mason, and Gurses (2007) have found, strong economic conditions reduce the probability of renewed civil war. Though an independent judiciary may be limited in directly allocating economic resources, it can aid in economic growth and development, and thus lead to a more sustainable peace in the aftermath of conflict.

A multitude of insecurities between fractious groups endure at the end of a civil war. On top of the political and economic concerns, a fundamental mistrust persists involving the implementation of settlement provisions after negotiation has occurred (Hartzell 1999, 6). Each side in a conflict is concerned about the enactment of provisions and if they will be successfully implemented. They are distrustful of the other and worry that the other group will renege on the agreements. An independent judicial system, serving as a fair conciliator, can help enforce the settlement designs to balance power between factions and to prevent any one party from dominance. If institutions serve to facilitate social interaction by reducing uncertainty, judicial systems can help ward off uneasiness by ensuring a fair and equal administration of settlement stipulations. Independent judiciaries can turn the promises offered by agreements into credible commitments.

Researchers addressing security dilemmas at the end of civil war have noted the importance that political institutions serve in maintaining stability. They claim that institutions play a large role in neutralizing the security dilemmas faced by opponents. Institutions facilitate the move by groups toward more cooperative relations. Weak institutions increase insecurities among rival groups. Institutions that contribute to political inclusiveness are more effective in stabilizing peace (Hartzell 1999; Walter 2004). Since the literature lacks specificity in the description of what these institutions look like, I argue that an independent judiciary can function 
as such an institution; that independent judicial systems encompass the security-assuring qualities associated with general political institutions.

Independent judicial systems instill legitimacy in the political environment. They assure opposing sides that there is an effective political entity to address grievances and that there will not be an indiscriminate application of the rule of law. Independent judiciaries mediate between the public and the government and provide an assurance that government power will be kept in check. In the aftermath of conflict, tension and distrust are high among societal groups; having an independent judicial system can help assuage these fears by encouraging a stable and accountable political system. A fair and neutral arbiter that serves to mitigate contentions, properly enforces legal provisions, and provides an outlet for political grievances will maintain a stable environment that is conducive to reconciliation and the maintenance of long-standing peace. Taking this theoretical argument into account, the following hypothesis was constructed:

H1: The establishment of an independent judiciary in post-conflict societies will lead to longer durations of peace.

\section{Research Design}

The aim of this paper was to analyze the impact that an independent judiciary has on peace duration in post-conflict societies. To properly assess the influence of this institution, parameters were set and defined. I tested my hypothesis using Mason et al.'s (2011) dataset on civil wars that started between 1945 and 2002. For reasons that will be explained later, not all years in this dataset were included. The criteria that determine the start and end dates of a civil war are precise; determining these dates was crucial in examining durations of peace in the aftermath of conflict. 
The dependent variable in this study was peace duration. I defined peace duration as it is defined in Mason et al. (2011):

A peace spell begins once all civil wars in a nation have terminated; a peace spell is considered to be persisting until a new civil war occurs. A peace spell ends when any new civil war occurs in a country; it is not focused on the recurrence or non-recurrence of a particular conflict dyad but overall conflict. Assessing the duration of overall peace is a better measurement in determining the effect that specific political institutions play in facilitating peace.

I wanted to understand the role that an independent judiciary plays in maintaining peace in a nation as a whole, not just in a particular conflict. The effectiveness of an institution in promoting peace must include the absence of all conflict if it is to properly assess how institutions ameliorate the conditions that lead to renewed conflict. Thus, countrywide peace longevity was the focus of my analysis.

The independent variable in this study was the presence of an independent judiciary. The CIRI Human Rights Data Project (Cingranelli and Richards 2008) provides a coding system that determines the level of judicial independence in a country. I used the definitions and coding measures that CIRI has used to assess both the presence of an independent judiciary and its level of independence. The dataset covers the years 1981 through 2010. Since I was trying to assess the correlation between peace duration post-conflict and the presence of an independent judiciary, I only assessed the years between 1981 and 2002 because the dataset on civil wars ends in that year (Mason et al. 2011). The CIRI dataset includes countries that have not undergone civil conflict but those countries were excluded in my analysis. The CIRI Human Rights Data Project codes the level of judicial independence in an ordinal 
manner. A country receives a coding of 2 if the judiciary possesses the following attributes:

“(1) It has the right to rule on the constitutionality of legislative acts and executive decrees; (2)

Judges at the highest level of courts have a minimum of a seven-year tenure; (3) The President or Minister of Justice cannot directly appoint or remove judges. The removal of judges is restricted (e.g. allowed for criminal misconduct). (4) Actions of the executive and legislative branch can be challenged in the courts. (5) All court hearings are public; and 6) Judgeships are held by professionals" (Cingranelli and Richards 2008, 95).

Structural limitations on judicial independence exist in countries that receive a score of 1 . Examples of limitations include the following:

“(1) The ability of the chief executive or minister of justice to appoint and dismiss judges at will, even if they do not actually do so in the particular year being coded; (2) Short periods of appointment (under seven years); (3) There is limited corruption or intimidation of the judiciary. The source of corruption and intimidation can be either inside or outside government; (4) Judges rule against the government in some, but not all potential cases, at times avoiding government-related cases or giving in to government pressure to rule in the government's favor; and (5) The US State Department (USSD) report mentions a concern about the independence of the judiciary raised by another organization." (Cingranelli and Richards 2008, 96)

Countries that receive a zero have active and widespread constraints on the judiciary. Examples include: “1) active government interference in the outcome of cases; 2) the dismissal of judges for political reasons; and 3) widespread corruption and intimidation of the judiciary. The sources of corruption and intimidation can be either inside or outside government" (Cingranelli and Richards 2008, 96). 
I chose to use this coding system and dataset for several reasons. First, it includes numerous countries and country-years. Since an assessment of judicial independence and its effect on peace duration has not been conducted, it was important that my analysis included a proper sample size. This dataset provides an adequate number of cases to assess. The definitions laid out by the CIRI Project are also explicit and clear. They specifically note the differences in the constraints on judicial power and how it affects the notion of what constitutes an independent institution. By detailing the attributes of the different levels of independence, the definitions provide a clear picture of why a judiciary would be deemed independent, partially independent, or not independent.

In this study, I controlled for variables that previous studies have found to have an effect on peace duration. These variables include the level of democracy within a country, the duration of the previous conflict, the intensity of the previous conflict, the level of economic development in a country, the presence of a negotiated settlement in a country, the rate of ethnic fractionalization in a country, the causes of the previous conflict, and the presence of UN peacekeeping operations in a country.

The level of democracy in a nation was measured using Polity IV. This widely used measure determines how autocratic or democratic a country is based on a 21-point scale, ranging from -10 to 10 . I expected to find that strong democracies and strong autocracies in post-conflict environments reduce the likelihood of war recurrence, in agreement with the findings in Mason et al. (2011). To account for the U-shaped relationship that exists between high democratic scores and high autocratic scores, I also used the square of the Polity IV measure for each peace year in a country.

The duration of the previous conflict is the number of years a conflict lasted. This measure 
is important to control for because, as noted in Hartzell, Hoddie, and Rothchild (2001) and Walter (2004), extended periods of domestic conflict are more likely to decrease the onset of renewed war. The number of war deaths in a conflict measures the intensity of the previous conflict. This is important to control for because there is uncertainty surrounding how this number affects the likelihood of conflict. Some research suggests that higher casualty rates positively affect the onset of renewed war by heightening levels of distrust in the post-conflict environment (Hartzell and Hoddie 2003). Other findings suggest that higher casualty rates negatively affect the onset of renewed conflict by demonstrating the futility of combat to opposition groups and lessening the number of potential recruits for new rebel armies (Quinn, Mason, and Gurses 2007; Walter 2004).

The level of economic development was measured by infant mortality rates (IMR). Infant mortality serves as a proxy for economic development because it takes into account the distribution of economic resources in a society. The way governments promote economic development and how governments decide to allocate resources is reflected in the measure (Abouharb and Kimball 2007). This factor is important when assessing the onset of conflict. Is it just poverty that affects the rates of conflict, or the misdistribution of economic resources? Using GDP per capita as a measure for economic development is not reflective of these questions concerning distribution. Overall, GDP per capita is a weaker indicator of the actual level of inequality in a nation. For these reasons, I chose to use IMR to assess levels of economic development as Walter (2004) and Mason et al. (2011) have.

A negotiation is said to have taken place if representatives of opposing sides in a conflict hold face-to-face talks and efforts to implement the provisions of the settlement are made. When these conditions are met, it will be said that a negotiated settlement is present. The data in Mason 
et al. (2011) found that negotiated settlements combined with international peacekeeping forces produce a peace that is more stable than peace following a government victory, suggesting that the presence of a settlement agreement has a positive effect on the duration of peace. Similarly, Hartzell, Hoddie, and Rothchild (2001) found that arrangements for territorial autonomy provisions in negotiated settlements have a positive correlation with peace preservation. Hartzell and Hoddie (2003) found that the incorporation of multiple dimensions of power-sharing in a negotiated civil war settlement is beneficial to the prospects of long-term peace. Since this is the case, I also included a variable that accounted for the presence of these types of arrangements. All of these findings assert that the presence of a negotiated settlement has a beneficial impact on peace duration, although the exact settlement provisions vary by situation.

The level of ethnic fractionalization was measured through Fearon and Laitin's (2003) ethnic fractionalization index. This index has been used in recent studies (see for example Mason et al. 2011) and is extensive in its breakdown of different ethnic groups that exist in a country. The causes of the previous civil war were assessed using the same method as Mason et al. (2011) by taking into account whether an earlier war was fought over territory or not. Territorial dispute is an important factor to control for because it affects the makeup of the post-conflict environment and is an influential factor in determining the onset of conflict. As Hensel and Mitchell (2005) claim, “...territorial issues escalate to war and produce protracted conflicts and enduring rivalries more frequently than other issues" (275).

The presence of UN Peacekeeping forces was examined through the same measures that Mason et al. (2011) used to generate peacekeeping variables, the UN DPKO Website (Doyle and Sambanis 2000, Fortna 2004, and Sambanis 2004). Since the presence of UN Peacekeeping operations have been found to positively affect the duration of peace in post-conflict societies 
(Mason et al. 2011; Sambanis 2004; Walter 2004) it was important to control this variable. Controlling for this variable allowed significant relationships with other variables to emerge.

To evaluate the effect that these variables have on peace duration, I used the Cox Proportional Hazard Model, which measures the risk of an event occurring. Controlling for different factors can increase the risk of happening, giving me positive coefficients, or decrease the risk of happening, giving me negative coefficients. Since I used much of the data in Mason et al. (2011) and he employed a hazard model, I wanted to limit variation by using the same measurement. I used a hazard model instead of a logit model because hazard models consider duration, while logit models do not. Logit models assess the probability of an event happening. By using a Cox Hazard Model I assessed how the variables I tested increased or decreased the risk for conflict onset, which helped identify factors that contributed to the duration of peace in post-conflict societies.

\section{Findings \& Analysis}

After running the Cox hazard model, it was found that the presence of an independent judiciary had no statistically significant impact on peace duration. The coefficient for the variable was in the positive direction and the $\mathrm{Z}$ value was too high to be considered significant.

Immediately after running the first model, I added an education variable to see if that would impact the results (World Bank Indicators). Education may affect how this institution's functionality is perceived. I chose a variable that measured the duration of primary education (in years) in a given country to assess a basic level of education in a country. When the model took into account the additional variable, there was still no statistically significant relationship between the presence of an independent judiciary and peace duration. 
There are a variety of reasons that may explain this lack of significance. It may be that there were not enough observations in the dataset. After merging the data and running the hazard model, only 361 observations remained in the first model and 347 in the second. This relatively small sample size may have decreased the robustness of this test. It may also be that the CIRI measure was an inaccurate measure of judicial independence. The scores given to the countries in the dataset reflected outside observations of these institutions and did not take into account public perception of the judiciary. This type of survey data was not available to test in the model. If a population is not aware of the independence of a judiciary or perceives it negatively, it may be unwilling to utilize the institution.

Additionally, it may be that the presence of an independent judiciary is not sufficient; public confidence in the institution may be important, as well as how frequently the institution is functioning. If people are not using the institution, whether due to reluctance, low political efficacy, or mistrust, it cannot have the proper effect it is supposed to have.

Further data needs to be collected to assess how frequently these judiciaries were assembled, tried cases, ruled on laws, and settled disputes and other claims. The activity rate of judiciaries was not taken into account in this study, which may explain some of the statistical insignificance.

Another explanation may be that in the country-years examined, enough time did not pass for an independent judiciary to have a positive impact on post-conflict society. If an institution is not given enough time to properly establish itself, it may have low functionality and utility. If an institution is not fully embedded in the post-conflict political environment, it may not be able to serve as it normally would. The post-conflict atmosphere is wrought with both societal and political uncertainty. Institutions that are not in place for extended periods of time may not be 
able to completely ameliorate these uncertainties; they may need more time to become entrenched. Establishing the rule of law in a country is also an arduous process that requires a lot of time. Even though an independent judicial system may be present in a country, it may have not had enough time to properly establish the rule of law.

It may also be that the judiciary does not have full control in the establishment of the rule of law. The executive branch may serve a stronger role in establishing the rule of law through the enforcement of laws. If the executive undermines court decisions or supersedes judicial precedent, the role that a judiciary plays in society diminishes. Independent judiciaries may be able to serve as arbitrators by monitoring human rights violations, for example, but it may not have the power to effectively prevent such abuses from occurring thereafter.

Elaborating on the notion that intergovernmental contentions may occur between different branches, perhaps the establishment of an institution that is separate from the executive makes the post-conflict political environment more volatile. The judiciary may increase institutional antagonisms by undermining the power of the executive. An independent judiciary may not be fully depoliticized if it is in direct contention with other branches of the government. Having separate branches of government may destabilize the political environment by increasing intergovernmental tensions. Even though the $\mathrm{Z}$ value for judicial independence was not significant, this argument may explain why the coefficient for the variable was in the positive direction.

\section{Conclusion}

The aim of this paper was to research a previously unexplored area of political institution building in post-conflict societies. The existing literature on post-conflict environments has suggested that mitigating security dilemmas is at the foundation of ensuring durable peace and 
that the presence of political institutions that safeguard against security dilemmas are necessary in guaranteeing this stability. The primary argument I set forth was that the presence of an independent judiciary would contribute to longer durations of peace in the aftermath of civil war. I argued that an independent judiciary was endowed with the security-assuring attributes that previous literature claimed to be necessary for political institutions to have in order to facilitate peace in post-conflict environments. I argued that independent judiciaries could alleviate security dilemmas by ending conditions of dual sovereignty in the post-conflict environment, increasing public access to political participation, encouraging conditions conducive to economic growth, and monitoring the fair enactment of settlement agreements. I proposed that an independent judiciary, serving as a neutral arbiter between warring factions, could function as a dependable political entity in ensuring the rule of law in the aftermath of conflict and instilling trust in the political system.

The empirical tests conducted in this paper did not support the theoretical argument I put proposed in terms of the role that independent judiciaries play in maintaining peace. As noted before, there were possible flaws with my research design and the way some of the variables were operationalized. It is possible that the coding I used to determine judicial independence was imprudent. For future research in this field, it will be important to collect survey data on public perceptions of the independence of judicial systems. The mere presence of an independent judiciary may not be sufficient to ensure durable peace; perhaps there must be public confidence in these institutions as well.

Further research should also investigate the activity rate of judiciaries to determine how practical they truly are. There needs to be further inquiry into the amount of work individual judiciaries do, by gauging the number of trials heard, the number of times government decisions 
are overruled or upheld, and the number of times the judiciary plays a direct role in monitoring the implementation of settlement provisions. The arguments I set forth about independent judiciaries may still hold, but more detailed and thorough research needs to be done that takes the aforementioned factors into account. Further research should also expand the dataset that I used. Expanding the data set to cover civil wars since 1945 and up until 2012 will decrease robustness issues in the data measurement.

Although the initial findings regarding the effect of judicial independence on peace duration were not significant, ample room remains for future inquiry. This endeavor has shed light into the need to study specific political institutions in post-conflict societies. Since previous literature has already suggested that political institutions help maintain peace after civil war, researchers must now determine which specific institutions contribute to this process and which ones are more effective than others. Identifying the institutions that are crucial to peace maintenance has practical implications for policy formation in post-conflict societies. Determining which institutions are the most effective in facilitating peace will help policymakers have a more focused and driven policy agenda that aims to resolve the underlying security problems that persist in the aftermath of conflict. 


\section{References}

Abouharb, M. R., and A. L. Kimball. 2007. "A New Dataset on Infant Mortality Rates, 1816 2002." Journal of Peace Research 44 (6):743-754.

Acemoglu, Daron, Simon Johnson and James A. Robinson. 2001. "The Colonial Origins of Comparative Development: An Empirical Investigation." American Economic Review 91:1369-1401.

Bakke, Kristin M. and Erik Wibbels. 2006. "Diversity, Disparity, and Civil Conflict in Federal States." World Politics 59 (1):1-50.

Barro, Robert J. 1997. Determinants of Economic Growth: A Cross-Country Empirical Study. MIT Press 1:1-79.

Bigombe, Betty, Paul Collier, and Nicholas Sambanis. 2000. "Policies for Building Post-Conflict Peace." Journal of African Economies 3:23-348.

Cingranelli, David L. and David L. Richards. 2008. The Cingranelli-Richards (CIRI) Human Rights Data Project Coding Manual Version 2008.3.13.

Doyle, Michael, and Nicholas Sambanis. 2000 "International Peacebuilding: A Theoretical and Quantitative Analysis.” American Political Science Review 94 (4):779-801.

Duverger, Maurice. 1995. Political Parties. New York: Wiley

Enweremadu, DU. 2009. "Judicial Reform and Democratic Consolidation in Nigeria." nimdesarp.org: 1999-2009.

Fearon, James D. and David D. Laitin. 2003. "Ethnicity, Insurgency, and Civil War.” The American Political Science Review 97 (1):75-90. http://www.jstor.org/stable/3118222

Fortna, Paige. 2004. "Does Peacekeeping Keep the Peace? International Intervention and the Duration of Peace after Civil War.” International Studies Quarterly 48 (2):269-292.

Hartzell, Caroline A. 1999. "Explaining the Stability of Negotiated Settlements to Intrastate Wars.” Journal of Conflict Resolution 43 (1):3-22.

Hartzell, Caroline. 2003. "Institutionalizing Peace: Power Sharing and Post-Civil War Conflict Management.” American Journal of Political Science 47 (2): 318-332.

Hartzell, Caroline, Matthew Hoddie and Donald Rothchild. 2001. "Stabilizing the Peace after Civil War: An Investigation of Some Key Variables.” International Organization 55 (1): 183-208. 
Hensel, Paul R., and Sara McLaughlin Mitchell. 2005. "Issue Indivisibility and Territorial Claims." GeoJournal 64 (4):275-285.

Horowitz, D. L. 1985. Ethnic Groups in Conflict. Berkeley, CA: University of California Press.

Larkins, C.M. 1996. "Judicial independence and Democratization: A Theoretical and Conceptual Analysis.” American Journal of Comparative Law 44: 605-626.

Linz, Juan J. 1992. “The Perils of Presidentialism.” Journal of Democracy 1 (1):51-69.

Mason, David, Mehmet Gurses, Patrick Brandt, and Jason Quinn. 2011. "When Civil Wars Recur: Conditions for Durable Peace after Civil Wars." International Studies Perspectives 12 (2):171-189.

North, Douglas C. 1990. Institutions, Institutional Change, and Economic Performance. New York: Cambridge University Press.

Quinn, J.M., T.D. Mason, and Mehmet Gurses. 2007. "Sustaining the peace: Determinants of civil war recurrence." International Interactions 1: 1-38.

Rugege, Sam. 2006. "Judicial Independence in Rwanda." Pacific McGeorge Global Business \& Development Law Journal 411-425.

Sambanis, Nicholas. (2004) "What Is Civil War? Conceptual and Empirical Complexities of an Operational Definition." Journal of Conflict Resolution 48 (6):814-858.

Smithey, S.I. and John Ishiyama. 2000. "Judicious choices : designing courts in post- communist politics.” Communist and Post-Communist Studies 33:163-182.

Smithey, S.I. 2002. "Judicial Activism in Post-Communist Politics." Law and Society Review 36:719-742.

Staton, J, and Christopher Reenock. 2010. "Judicial Independence and the Democratic Order." Annual Meeting of the Southern 404.

Tilly, Charles. 1978. From Mobilization to Revolution. Reading, MA: Addison Wesley.

Walter, B.F. 2004. "Does conflict beget conflict? Explaining recurring civil war." Journal of Peace Research 41 (3):371-388.

World Bank. World Bank.org. Accessed 7/10/2012 http://data.worldbank.org/indicator 
Table 1. Hazard Analysis of Peace Duration

\begin{tabular}{lrr}
\hline Independent Variables & Coefficient & $\mathrm{P}>|\mathrm{z}|$ \\
Judicial Independence & .909 & $0.087^{*}$ \\
Infant Mortality Rate & .031 & 0.122 \\
Ethnic Fractionalization & 1.47 & 0.707 \\
War Duration & -.274 & $0.004^{* * *}$ \\
Battle Deaths & $1.81 \mathrm{e}-06$ & 0.197 \\
Polity IV squared & -.056 & $0.033^{* *}$ \\
Negotiated Settlement & 1.09 & 0.240 \\
Power Sharing Arrangement & -.634 & 0.439 \\
Territorial Dispute & .316 & 0.691 \\
UN Peace Keeping Operations & -1.36 & 0.184 \\
N=361 & & \\
\hline
\end{tabular}

*Significance at .10 level; **significance at .05 level; ***significance at .01 level Dependent Variable peace duration 
Table 2. Hazard Analysis of Peace Duration (with Additional Variable)

\begin{tabular}{lrr}
\hline Independent Variables & Coefficient & $\mathrm{P}>|\mathrm{z}|$ \\
Judicial Independence & .710 & 0.230 \\
Education & .604 & 0.396 \\
Infant Mortality Rate & .034 & 0.217 \\
Ethnic Fractionalization & 1.172 & 0.811 \\
War Duration & -.304 & $0.000^{* * *}$ \\
Battle Deaths & $2.23 \mathrm{e}-06$ & $0.047^{* *}$ \\
Polity IV squared & -.06 & $0.018^{* *}$ \\
Negotiated Settlement & 1.532 & $0.062^{*}$ \\
Power Sharing Arrangement & -1.436 & 0.269 \\
Territorial Dispute & .973 & 0.452 \\
UN Peace Keeping Operations & -1.024 & 0.232 \\
N=347 & & \\
\hline
\end{tabular}

*Significance at .10 level; ${ }^{* *}$ significance at .05 level; ${ }^{* * *}$ significance at.01 level Dependent Variable peace duration 